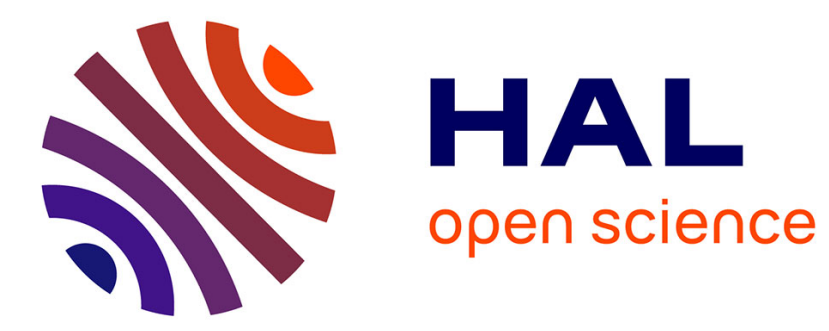

\title{
Engineering Properties of Grouted Sands
}

Christophe Dano, Pierre-Yves Hicher, S Tailliez

\section{To cite this version:}

Christophe Dano, Pierre-Yves Hicher, S Tailliez. Engineering Properties of Grouted Sands. Journal of Geotechnical and Geoenvironmental Engineering, 2004, 130 (3), pp.328-338. 10.1061/(ASCE)10900241(2004)130:3(328) . hal-01501215

\section{HAL Id: hal-01501215 \\ https://hal.science/hal-01501215}

Submitted on 4 Apr 2017

HAL is a multi-disciplinary open access archive for the deposit and dissemination of scientific research documents, whether they are published or not. The documents may come from teaching and research institutions in France or abroad, or from public or private research centers.
L'archive ouverte pluridisciplinaire HAL, est destinée au dépôt et à la diffusion de documents scientifiques de niveau recherche, publiés ou non, émanant des établissements d'enseignement et de recherche français ou étrangers, des laboratoires publics ou privés. 


\title{
Engineering Properties of Grouted Sands
}

\author{
C. Dano'; P.-Y. Hicher ${ }^{2}$; and S. Tailliez ${ }^{3}$
}

\begin{abstract}
A comparison of the behavior of uncemented and grouted sands is presented. Four sands (Fontainebleau sand and three types of alluvial deposits of the Seine River) were tested. Specimens of grouted sands were prepared in the laboratory by injection of very fine cement or mineral grouts. An initial series of unconfined uniaxial compression tests and tensile tests was performed to highlight the effect of some key factors (mainly the cement-to-water ratio of the grout and the relative density of the granular skeleton) on the strength of the grouted sands. Subsequent triaxial tests showed that when a soil is impregnated by either a very fine cement grout or a mineral grout, both stiffness (secant stiffness or small-strain stiffness) and strength of the soil improve. Similar trends were observed for the behavior of both uncemented and grouted sands. The behavior of grouted sands can be roughly reproduced by applying a linear elastic, perfectly plastic model with a nonassociated Mohr-Coulomb yield criterion whose parameters can be easily determined. Finally, preliminary recommendations are proposed relative to improvements ratios of the parameters of this simple constitutive model that is still commonly used in geotechnical engineering.
\end{abstract}

CE Database subject headings: Grouting; Elastic properties; Experimental data; Sand.

\section{Introduction}

The construction of underground structures on soft ground often requires the soil to be improved in order to ensure the safety and the stability of surrounding buildings. Grout permeation is an efficient technique for reducing permeability and for increasing stiffness and strength of coarse-to-medium grained soils with low initial mechanical properties.

Traditional organic grouts, such as silicate gels, have proved to be hazardous for groundwater such that organic grouts have been prohibited over the years. New grouts, therefore, such as very fine cement suspensions and mineral grouts, have been developed for about the past 20 years (Zebovitz et al. 1989; Benhamou 1994). These new grouts present similar groutability performance as do previous chemical solutions. Their considerable advantage is that they prove to be stable with time.

This paper reports the results of an evaluation of the mechanical behavior of sands improved with these new grouts. Some grouted sands were prepared in the laboratory, others were sampled from in situ impregnated soils.

\section{Behavior of Laboratory Grouted Sands}

An extensive review of published experimental results relative to grouted sands reveals a large discrepancy of the results due to a

\footnotetext{
${ }^{1}$ Associate Professor, Research Institute in Civil and Mechanical Engineering, Ecole Centrale de Nantes, BP 92101, 44321 Nantes, France.

${ }^{2}$ Professor, Research Institute in Civil and Mechanical Engineering, Ecole Centrale de Nantes, BP 92101, 44321 Nantes, France.

${ }^{3} \mathrm{PhD}$, Civil Engineer, Coyne-et-Bellier, 9 allée des Barbanniers, 92632 Gennevilliers, France.
}

wide variety of parameters relative to (Zebovitz et al. 1989; Schwarz and Krizek 1994; Tailliez 1998; Schillinger et al. 2000)

- The soil (grain-size distribution, mineralogy, soil density, specific area);

- The grout (nature, cementitious material-to-water ratio, particle-size distribution); and

- The injection conditions (rate of discharge, grout pressure, injection procedure).

Even if trends are drawn from studies inevitably restricted to some of these parameters, and key factors are pointed out in the case of naturally or artificially cemented sands, these reported results still would not allow one to propose standard design rules.

As a result, experimental observations from the literature based on cement-treated sands are supported by mechanical tests performed using grouted sands in this study. These tests are performed either by conventional laboratory testing (unconfined uniaxial compression tests, tensile tests, triaxial tests) or by innovative experiments for the determination of elastic properties in a small-strain domain.

\section{Materials}

Four natural uncemented sands, namely the Fontainebleau NE34 sand (termed FS) and three alluvial deposits of the Seine River [Seine River Sand (SRS), medium alluvial deposit (ADM) and coarse alluvial deposit (ADC)], were improved with three patented grouts. The characteristics of the tested soils are indicated in Table 1. The Fontainebleau sand (FS) is a standard fine siliceous uniform sand, whereas the SRS and the alluvial deposits (ADM, ADC) are silico-calcareous gravelly sands. Fig. 1 shows their respective grain-size distribution curves. The natural gradation of the SRS and of the alluvial deposits (ADM, ADC) were reduced to a particle size of 2.5 and of $10 \mathrm{~mm}$, respectively. The largest particles contained within the test specimens were therefore smaller than one tenth of the specimen diameter. Particles of the tested sands present a subrounded or subangular shape.

Three mix designs of an initial very fine cement grout (CG) (i.e., CG1, CG2, and CG3), three mix designs of a mineral solu- 
Table 1. Characteristics of Sands

\begin{tabular}{|c|c|c|c|c|}
\hline $\begin{array}{l}\text { Sand } \\
\text { Standards }\end{array}$ & $U_{c}=d_{60} / d_{10}{ }^{\mathrm{a}}$ & $\begin{array}{l}d_{50}^{\mathrm{b}} \\
(\mu \mathrm{m})\end{array}$ & $\begin{array}{c}\gamma_{\min } \\
\left(\mathrm{kN} / \mathrm{m}^{3}\right) \\
\text { ASTM D4254-91 }\end{array}$ & $\begin{array}{c}\gamma_{\max } \\
\left(\mathrm{kN} / \mathrm{m}^{3}\right) \\
\text { ASTM D4253-93 }\end{array}$ \\
\hline Fontainebleau sand (FS) & 1.4 & 200 & 13.7 & 17.2 \\
\hline Seine River sand (SRS) & 3.5 & 530 & 14.4 & 18.2 \\
\hline Medium alluvial deposits (ADM) & 2.1 & 410 & 14.9 & 17.9 \\
\hline Coarse alluvial deposits (ADC) & 5.9 & 1,300 & 16.4 & 19.4 \\
\hline Dunkerque sand (DS) & 3.1 & 240 & - & - \\
\hline
\end{tabular}

${ }^{\mathrm{a}} U_{c}$ is coefficient of uniformity.

${ }^{\mathrm{d}} d_{10}, d_{60}$ is grain size at which 10 and $60 \%$ of particles by weight, respectively, are smaller. $d_{50}$ is mean grain size.

${ }^{\mathrm{c}} \gamma_{\text {min }}$ is minimum dry unit weight.

${ }^{\mathrm{d}} \gamma_{\max }$ is maximum dry unit weight.

tion (i.e., MG1, MG2, MG3) (Gouvenot 1995) and six mix designs of a subsequent very fine cement grout (i.e., IJ1, IJ2, IJ3, IJ4, IJ5, and IJ6) were proposed, as shown in Table 2. The dry material-to-water ratio is $(M / W)$; the cement-to-water ratio is $(C / W)$ (Table 2). The particle sizes of the cementitious grouts are less than $12 \mu \mathrm{m}$, as shown in Fig. 1. Their rheological properties, including a low plastic viscosity and a low yield shear stress, are maintained at essentially constant values during the injection phase by the use of dispersing agents, superplasticizer admixtures, and high-speed mixers. The grout stability ensured an effective permeation of the grouts through the sands.

\section{Laboratory Preparation of Grouted Sands}

The preparation of the grouted sands in the laboratory follows a systematic procedure inspired by previously published injection devices (Zebovitz et al. 1989; Benhamou 1994; Schwarz and Krizek 1994; Tailliez 1998). Improvements in the permeation grouting process and in checking the grouted samples have been made. A detailed description of the procedure can be found in Dano and Derache (2001). Briefly, the sand was placed with a zero fall height in a transparent and rigid cylindrical column made of polyvinyl chloride (PVC). The diameter of the tube was 80 or $100 \mathrm{~mm}$, and its height was $900 \mathrm{~mm}$. As the inner tube was being pulled up, as illustrated in Fig. 2, a few simultaneous hammer strokes on the PVC tube compacted the soil. This method induced

Table 2. Grouts and Grouted Sands Unconfined Compressive strengths (ASTM D 2166-91)

\begin{tabular}{lcccc}
\hline Grout & $\begin{array}{c}\text { Dry material } \\
\text { to water ratio }\end{array}$ & $\begin{array}{c}\text { Cement to } \\
\text { water ratio }\end{array}$ & $\begin{array}{c}R_{c, \mathrm{PG}}{ }^{\mathrm{a}} \\
(\mathrm{MPa})\end{array}$ & $\begin{array}{c}R_{c}{ }^{\mathrm{b}} \\
(\mathrm{MPa})\end{array}$ \\
\hline Cementitious grout (CG1) & 0.2 & 0.07 & - & 0.9 \\
Cementitious grout (CG2) & 0.2 & 0.11 & - & 1.1 \\
Cementitious grout (CG3) & 0.2 & 0.15 & - & 1.9 \\
Mineral grout (MG1) & 0.3 & 0.056 & - & 0.6 \\
Mineral grout (MG2) & 0.3 & 0.078 & - & 0.9 \\
Mineral grout (MG3) & 0.26 & 0.123 & - & 1.9 \\
Cementitious grout IJ1 & - & 0.17 & 0.8 & 1.1 \\
Cementitious grout IJ2 & - & 0.23 & 1.9 & 2.5 \\
Cementitious grout IJ3 & - & 0.29 & - & 3.2 \\
Cementitious grout IJ4 & - & 0.34 & 4.2 & 5.1 \\
Cementitious grout IJ5 & - & 0.40 & 5.6 & 6.4 \\
Cementitious grout IJ6 & - & 0.46 & 7.7 & 8.5 \\
\hline
\end{tabular}

${ }^{\mathrm{a}} R_{c, \mathrm{PG}}$ is unconfined compressive strength of the pure grout.

${ }^{\mathrm{b}} R_{c}$ is unconfined compressive strength of the grouted sand. a satisfactory homogeneity for the soil. This procedure was also found to be repeatable for high relative densities of the granular skeleton, where the relative density $D_{r}$ is defined as follows:

$$
D_{r}=\frac{\gamma_{\max }}{\gamma} \times \frac{\gamma-\gamma_{\min }}{\gamma_{\max }-\gamma_{\min }}
$$

where $\gamma=$ dry unit weight of the soil; $\gamma_{\min }=$ its minimum dry unit weight (ASTM D 4254-91); and $\gamma_{\max }=$ its maximum dry unit weight (ASTM D 4253-93). The relative density of the samples subsequently tested was always greater than $90 \%$.

After the column was completely filled, some of the columns were saturated with water, while others were left dry. A fixed volume of grout equal to 1.2 times the initial volume of voids of the granular skeleton was then injected from the base to the top of the column at a constant volumetric flow rate of $3 \mathrm{~cm}^{3} / \mathrm{s}$. Grout permeation occurred without any significant pressure rise. Gradually the grout completely filled the intergranular voids without visible fabric change of the granular skeleton. The void ratio of the granular skeleton deposited in a dense state was not significantly changed, as evidenced by dry density measurements of grouted specimens.

Columns were kept in a humidity and temperature-controlled room for a period of 28 days. After this period, the mechanical properties of grouted samples became constant. Four samples with a height-to-diameter ratio equal to 2 were cut from each column. Their faces were made parallel and smooth by straightening, and they were subsequently subjected to mechanical tests.

\section{Unconfined Uniaxial Compression Strength}

Unconfined uniaxial compression tests (ASTM D 2166-91) are routinely performed to assess the effect of the previously men-

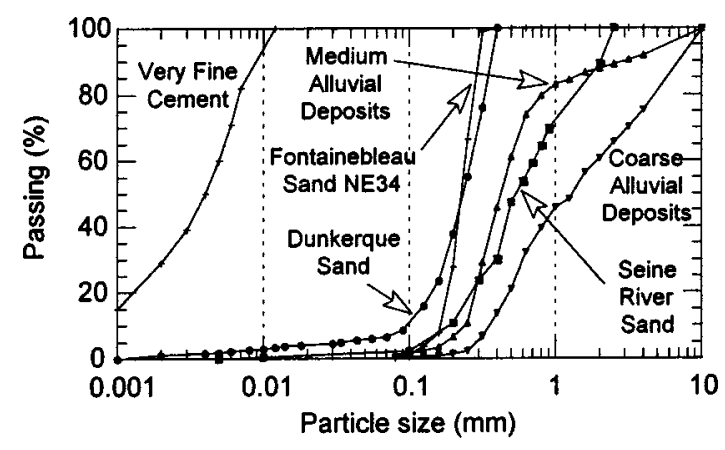

Fig. 1. Gradation curves of tested sands 


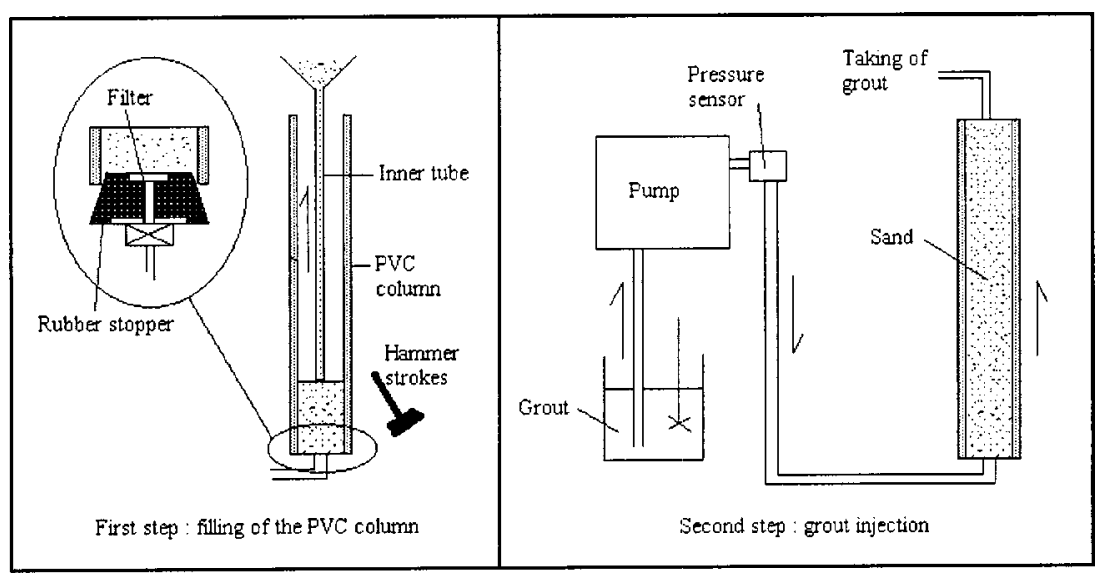

Fig. 2. Laboratory preparation of grouted sands

tioned parameters on the strength of the grouted sands. For most soil-cement mixtures, the strength depends mainly on the cement content of the grout and on the grain-size distribution, the mineralogy, and the relative density of the granular skeleton, regardless of the manufacturing process e.g., hand mixing, grout injection (Clough and Sitar 1981; Zebovitz et al. 1989; Airey 1993; Tailliez 1998). Some published results of the unconfined compressive strength, $R_{c}$, for sands injected with microfine cement grouts or mineral grouts as a function of the $C / W$ are reported in Fig. 3(a) (Zebovitz et al. 1989; Schwarz and Krizek 1994; Kutzner 1996; Tailliez 1998).

Fig. 3(b) shows the evolution of $R_{c}$ as a function of $D_{r}$ for three soils tested in this study (FS, ADM, ADC) for a similar cement-to-water ratio $(C / W=0.172)$, without saturation before grout injection. Three samples are tested for each relative density. The apparent scatter in the data is mainly due to the imperfect parallelism of the sample faces and to the injection process; i.e., the unconfined compressive strength of the three samples extracted from the same PVC column depends slightly on location from which the sample was extracted from the column. On the other hand, the scatter was small among samples from columns prepared under the same conditions. The unconfined compressive strength tends to increase with higher relative densities. Similar tendency was also found by Clough and Sitar (1981) and Huang and Airey (1998) for cemented sands. One possible explanation is that cementation is more effective in denser specimens because the particles are closer together.

The effect of the gradation is also highlighted in Fig. 3(b). The grouted FS shows greater unconfined compressive strengths than the alluvial deposits (ADM or ADC). However, further work will be necessary to disconnect the effect of the mean size $\left(d_{50}\right)$ of the particles (Saxena and Lastrico 1978; Zebovitz et al. 1989), the effect of the specific area of the sand grains (Kaga and Yonekura $1991)$, and the effect of the coefficient of uniformity $\left(U_{c}\right)$.

Fig. 3(c) represents the evolution of the unconfined compressive strength, $R_{c, \mathrm{PG}}$, of the pure microfine cement grout (IJ) and the evolution of the unconfined compressive strength, $R_{c}$, of the FS at $D_{r}=78 \%$, injected with the microfine cement grout IJ without initial water saturation. As previously mentioned, the unconfined compressive strength of the grouted sands increases as the cement-to-water ratio of the grout increases.

Kaga and Yonekura (1991) suggested that the unconfined compressive strength of the cemented sands, $R_{c}$, is related to the unconfined compressive strength of the cement paste, $R_{c, \mathrm{PG}}$, as follows:

$$
R_{c}=B+A_{\text {soil }} \times\left(R_{c, \mathrm{PG}}\right)^{n}
$$

where the parameters $A_{\text {soil }}, B$, and $n$ depend mainly on the soil relative density and on the specific area of the sand grains. Kaga and Yonekura (1991) also stated that the power $n$ depends linearly on the relative density $D_{r}$ as follows:

$$
n=n_{0}-n_{1} \times D_{r}
$$

where $n_{0}$ and $n_{1}=$ constants.

The parameter $B$ represents the unconfined compressive strength of the granular skeleton without any cement paste. Consequently, its value here is assumed to be equal to zero. Finally, the compressive strength of the grouted sand, $R_{c}$, is related to the compressive strength of the pure grout, $R_{c, \mathrm{PG}}$, as follows:

$$
R_{c}=A_{\text {soil }}\left(D_{r}\right) \times\left(R_{c, \mathrm{PG}}\right)^{n_{0}-n_{1} \times D_{r}}
$$

Based on results presented in Fig. 3(c) and in Table 2, $R_{c, \mathrm{PG}}$ is related to the cement-to-water ratio, $C / W$ as follows:

$$
R_{c, \mathrm{PG}}=A_{0} \times\left(\frac{C}{W}\right)^{N}
$$

The values of the two parameters $A_{0}$ and $N$ are determined by matching the experimental data [Fig. 3(c), Table 2]. In the case of the microfine cement grout (IJ), $A_{0}$ is equal to $45.3 \mathrm{MPa}$ and $N$ is close to 2.2 .

By combining Eqs. (4) and (5), $R_{c}$ of the grouted sand is related to the cement-to-water ratio $C / W$

$$
R_{c}=A_{\text {soil }}\left(D_{r}\right) \times A_{0}^{n_{0}-n_{1} \times D_{r}} \times\left(\frac{C}{W}\right)^{N \times\left(n_{0}-n_{1} \times D_{r}\right)}
$$

Matching the experimental data corresponding to the Fontainebleau sand $\left(D_{r}=78 \%\right)$ injected by the microfine cement grout (IJ) leads to the following equation:

$$
R_{c}=40.0 \times\left(\frac{C}{W}\right)^{2.0}
$$

Further work will be necessary to determine the mathematical expression for the function $A_{\text {soil }}\left(D_{r}\right)$, which depends on the relative density and on the nature of the soil, and to clarify the effect of each soil characteristic (for example, specific area, grain size, and mineralogy).

Unconfined compression tests were also performed to assess the effect of the shear rate on the strength of grouted sands. These tests were required because silicate-grouted sands generally show 


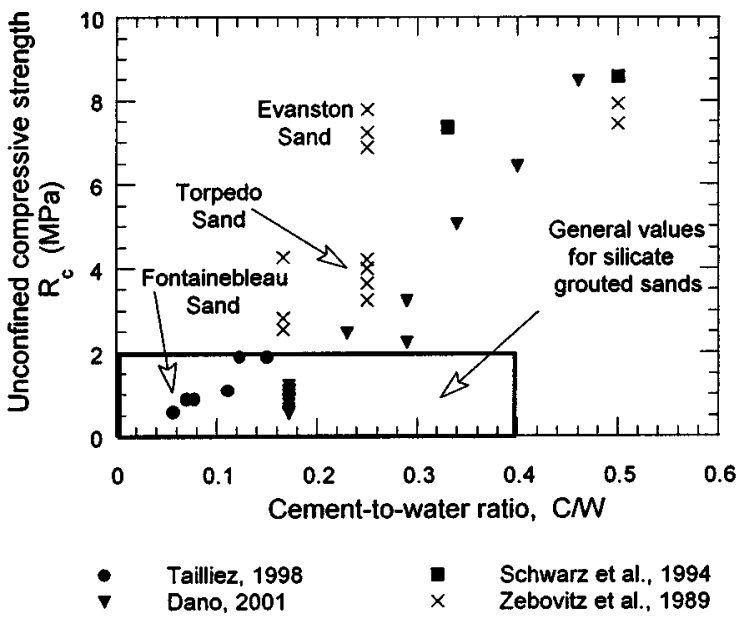

(a) Effect of the cement-to-water ratio $\mathrm{C} / \mathrm{W}$ of the cementitious grouts.

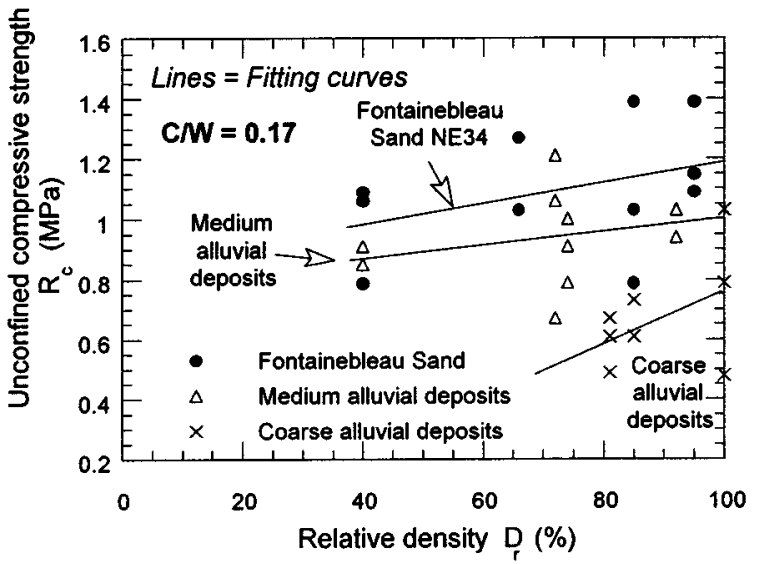

(b) Effect of the relative density $D_{r}$.

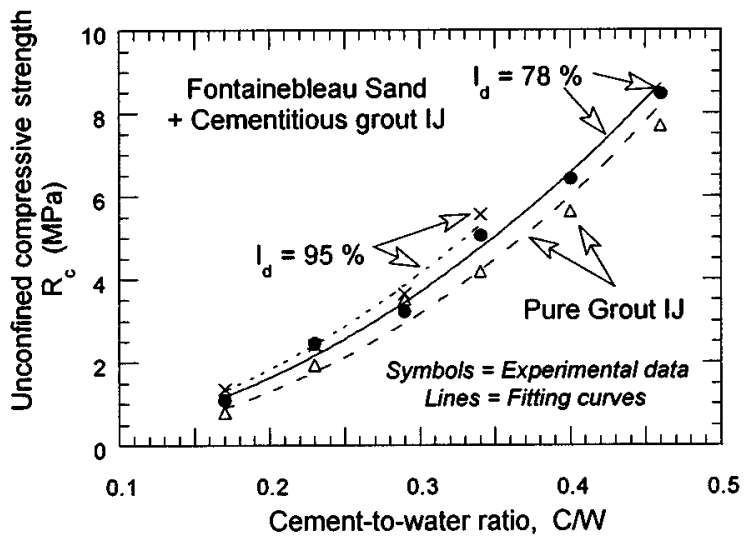

(c) Evolution of the unconfined compressive strength $R_{c}$ with $C / W$.

Fig. 3. Effect of cement to water, ratio and relative density $D_{r}$ on unconfined compressive strength $R_{c}$ of grouted sands (ASTM D 2166-91): (a) effect of cement to water ratio of cementitious grouts; (b) effect of relative density $D_{r}$; and (c) evolution of unconfined compressive strength $R_{c}$ with cement to water ratio

a viscous effect (Tailliez 1998), and different tests are performed in the field (pressuremeter tests for instance) with different strain rates than those used for triaxial tests.

Fig. 4 shows that the viscous effect in sands grouted by either pure microfine cements or mineral grouts can be disregarded for shear rates between $1.25 \times 10^{-2}$ and $12.5 \% / \mathrm{min}$.

\section{Tensile Strength}

The bonds produced by the hydration and the setting of the cement also provide a tensile strength for the soil-cement mixture. For example, Airey (1993) and Huang and Airey (1998) showed that the tensile strength of artificially cemented carbonate 


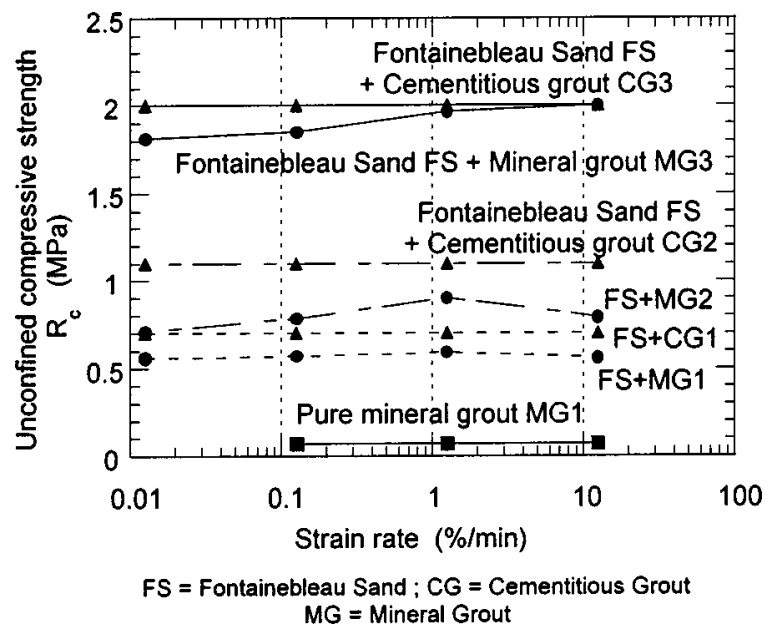

Fig. 4. Effect of strain rate on unconfined compressive strength $R_{c}$ of grout and grouted sands (ASTM D 2166-91)

soils depends on both the cement-to-water ratio and the soil density.

In the case of grouted sands, the tensile strength was experimentally evaluated from both splitting tensile tests (ASTM D 3967-92) and direct tensile tests (ASTM D 2936-84). In the latter case, the 80 -mm-diameter by $160-\mathrm{mm}$-height samples were glued to PVC pedestals with an epoxy resin (Araldite glue, Ciba Specialty Chemicals, U.K.). A clear failure surface perpendicular to the extension axis was observed in the upper part of the grouted samples, slightly above mid-height.

Values of the tensile strength measured by splitting tensile tests, $R_{\mathrm{TB} \text {,exp }}$, and the tensile strength determined by direct tensile tests, $R_{\mathrm{TD} \text {,exp }}$, for Fontainebleau sand samples first saturated, then injected with the microfine cement grouts (i.e., CG1, CG2, CG3) and the mineral grouts (i.e., MG1, MG2, MG3) are reported in Table 3. The splitting tensile strength was found to be approximately $18 \%$ of the unconfined compression strength for the microfine cement grout and approximately $7 \%$ for the mineral grout. The ratio between the direct tensile strength and the unconfined compression strength, $R_{\mathrm{TD}, \exp } / R_{c}$, was even lower, about $1-2 \%$. For comparison, Clough and Sitar (1981) indicated that the strength obtained by splitting tensile tests corresponded to $9-12 \%$ of the unconfined compression strength for cemented sands $\left(0.09 \leqslant R_{\mathrm{TB}, \exp } / R_{c} \leqslant 0.12\right)$. Also, for cemented carbonate sands, Huang and Airey (1998) reported ratios of tensile to compressive strengths, $R_{\mathrm{TB}, \exp } / R_{c}$, between 10 and $30 \%$.

If a Mohr-Coulomb yield criterion $F(\boldsymbol{\sigma})$ is assumed for the grouted sand $(\sigma<0$ in compression):

$$
F\left(\boldsymbol{\sigma}^{\prime}\right)=\left(\sigma_{3}^{\prime}-\sigma_{1}^{\prime}\right)+\left(\sigma_{3}^{\prime}+\sigma_{1}^{\prime}\right) \times \sin \varphi^{\prime}-2 c^{\prime} \times \cos \varphi^{\prime}
$$

where $\boldsymbol{\sigma}^{\prime}=$ stress tensor; $\sigma_{1}^{\prime}$ and $\sigma_{3}^{\prime}=$ minor principal stress and major principal stress, respectively $\left(\sigma_{1}^{\prime} \leqslant \sigma_{3}^{\prime}\right)$; $c^{\prime}=$ effective-stress cohesion; and $\varphi^{\prime}=$ effective-stress friction angle. The unconfined compression strength, $R_{c}$, and the direct tensile strength, $R_{\mathrm{TD} \text {,the }}$, are related to $c^{\prime}$ and $\varphi^{\prime}$ as follows:

$$
\begin{gathered}
R_{\mathrm{TD}, \text { the }}=\frac{2 c^{\prime} \times \cos \varphi^{\prime}}{1+\sin \varphi^{\prime}} \\
R_{c}=\frac{2 c^{\prime} \times \cos \varphi^{\prime}}{1-\sin \varphi^{\prime}}
\end{gathered}
$$

and $R_{\mathrm{TD} \text {,the }} / R_{c} \approx 20 \%$ for standard values of the friction angle. The large difference between $R_{c}$ and $R_{\mathrm{TD} \text {,exp }}$ found in this study means that the failure envelope is probably curved in the tensile stress domain. In other words, the relationship between the major and the minor principal stresses is not linear over a large domain of stresses as predicted by Griffith's crack theory (Hoek and Brown 1980; Kutzner 1996). However, the tensile strength is usually not taken into account in numerical computations for geotechnical design. Therefore, a linear failure envelope in the compressive domain will be assumed later.

\section{Triaxial Tests}

Although many studies have pointed out that the linear failure envelope, described by a friction angle and an intercept cohesion, does not exactly represent the actual failure envelope of soils and rocks (Bishop 1966; Baligh 1976), these parameters remain widely used in current geotechnical design. They can be determined by means of conventional consolidated-drained triaxial tests (French Standard NF P 94-074) which were carried out on saturated uncemented sands (with $B$ values always greater than $96 \%$ ) and on grouted sands prepared in the laboratory. Free water in grouted samples, due to the water saturation before grout injection, was smoothly removed by drying at room temperature. The effect of the drying procedure was not investigated but was assumed to be negligible. The axial strain rate was $1.25 \times 10^{-1} \% / \mathrm{min}$. Confining pressures were between 0.1 and $0.4 \mathrm{MPa}$ representing the vertical stress domain for tunnel works in urban areas (Bouvard-Lecoanet et al. 1992). The height-todiameter ratio of the samples was close to 2. No lubrication was applied to the end platens. The results are presented in terms of deviator stress $q$ and volumetric strain $\varepsilon_{v}$ versus axial strain $\varepsilon_{1}$. The axial strain $\varepsilon_{1}$ was calculated from the sample shortening measured on an external micrometer, which induces an experimental uncertainty due to bedding and compliance errors. This uncertainty is more pronounced in the case of stiff grouted sands. An internal load cell was used to determine the axial stress $\sigma_{1}$. Finally, sample volume changes were recorded either by measuring pore water exchanges (water expulsion in the contracting do-

\begin{tabular}{|c|c|c|c|c|c|c|c|}
\hline & & \multicolumn{3}{|c|}{ Fontainebleau sand+cementitious grout $(\mathrm{CG})$} & \multicolumn{3}{|c|}{ Fontainebleau sand + mineral grout $(\mathrm{MG})$} \\
\hline & & CG1 & CG2 & CG3 & MG1 & MG2 & MG3 \\
\hline$R_{c}$ & MPa & 0.9 & 1.1 & 1.9 & 0.6 & 0.9 & 1.9 \\
\hline$R_{\mathrm{TB}, \exp } / R_{c}$ & $\%$ & 17 & 23 & 16 & 8.3 & 7.8 & 6.8 \\
\hline$R_{\mathrm{TD}, \exp } / R_{c}$ & $\%$ & - & $1-1.25$ & - & - & $1.7-2$ & - \\
\hline$R_{\mathrm{TD}, \text { the }} / R_{c}$ & $\%$ & - & $20-25$ & - & - & $20-25$ & - \\
\hline
\end{tabular}
main or water absorption in the dilating phase) in a burette for

Table 3. Tensile Strength of Grouted Fontainebleau Sand

Note: $R_{c}$ is unconfined compressive strength; $R_{\mathrm{TB}, \text { exp }}$ is tensile strength measured by splitting tensile test (ASTM D 3967-92); $R_{\mathrm{TD}, \text { exp }}$ is tensile strength measured by direct tensile test (ASTM D 2936-84); $R_{\mathrm{TD}, \text { the }}$ is tensile strength obtained with the Mohr-Coulomb yield criterion. 

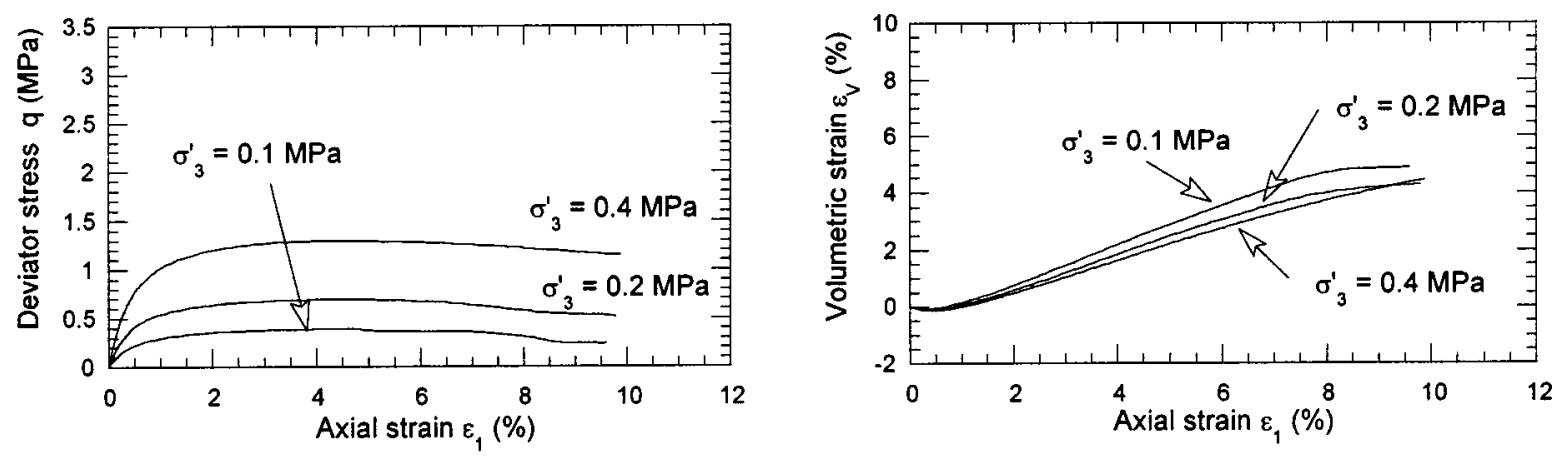

(5a) Fontainebleau Sand
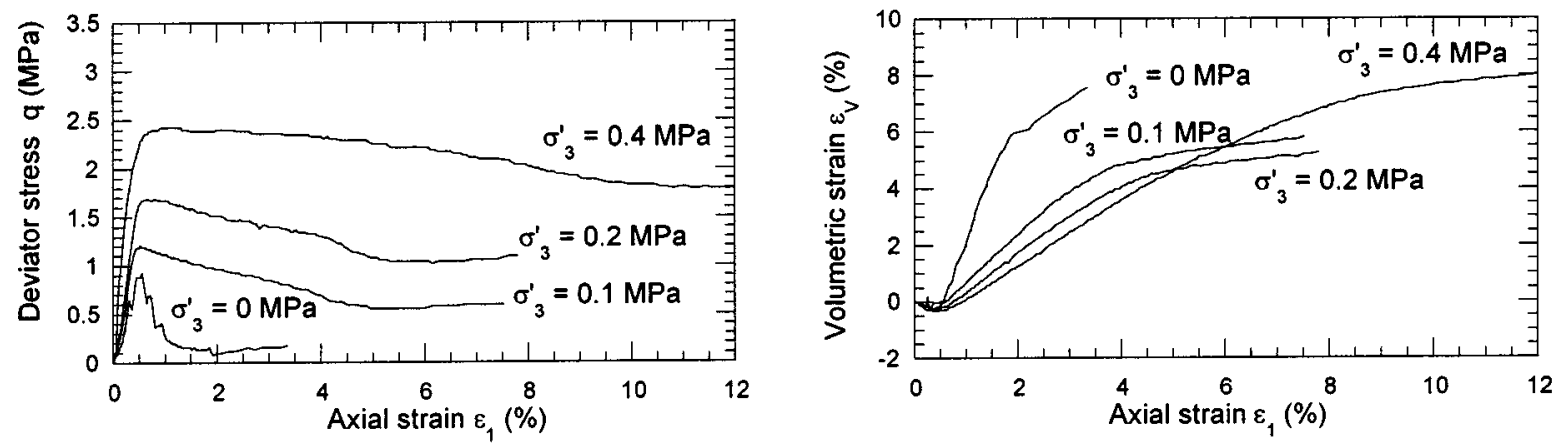

(5b) Fontainebleau Sand + Cementitious Grout CG 1
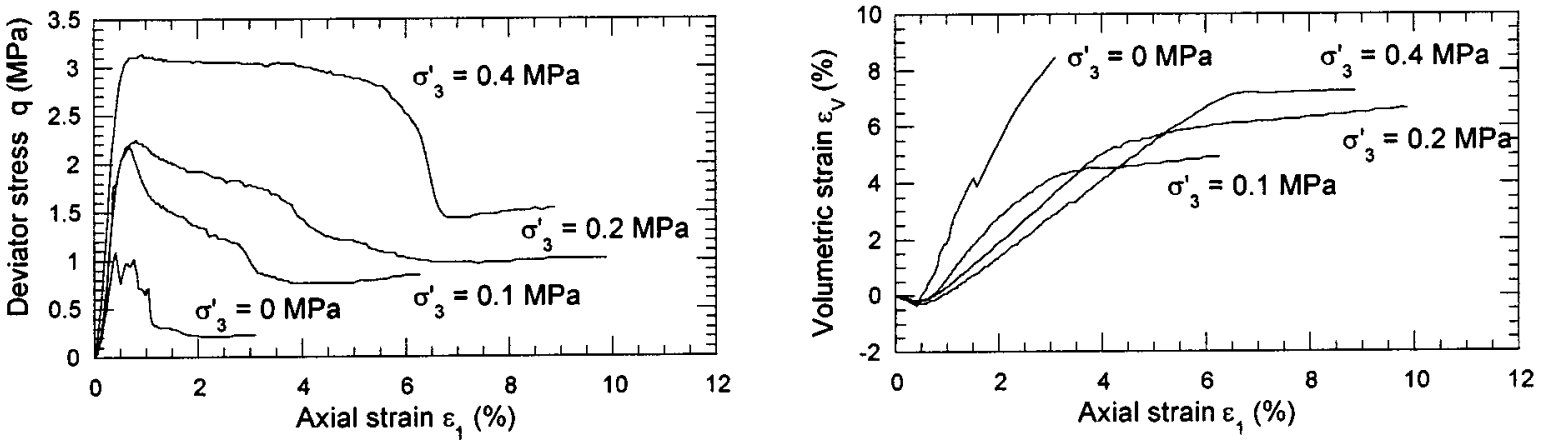

(5c) Fontainebleau Sand + Cementitious Grout CG 2

Fig. 5. Drained triaxial tests on Fontainebleau sand prepared in laboratory (AFNOR P 94-074) $\left(\sigma_{3}^{\prime}=\right.$ constant effective lateral stress during triaxial tests)

saturated uncemented samples, or by measuring volume changes of the cell fluid on the pressure-volume controller from which the confining pressure $\sigma_{c}$ was applied, provided that these volume changes were corrected from the load cell penetration, for grouted samples. Previous calibration tests showed that these two measurements were equivalent.

As shown in Figs. 5 and 6, the results of these tests illustrate the beneficial effect that the grout injection has on the strength and on the stiffness of the soil. They also confirm the following general trends for the cement-treated soils:

- Stiffness and strength increase as the binder content increases;

- The volumetric behavior is typically contractive-dilatant; and

- The postpeak behavior is more brittle for cementitious grouts, for low confining pressures, and for high cement contents.

Failure occurs with visible vertical cracks for high cement-towater ratios and low confining pressures, whereas strain localization with inclined shear bands occurs for low cement-to-water ratios and high confining pressures.

The cohesion $c^{\prime}$ due to cemented intergranular bonds and the friction angle $\varphi^{\prime}$ due to interparticle contacts were determined by plotting the failure envelope in the Mohr-Coulomb diagram. For uncemented granular soils, a straight-line failure envelope with zero cohesion is apparent, as shown in Fig. 7. For grouted sands (Fig. 7), a straight-line failure envelope that is almost parallel to that for the uncemented granular soil is apparent. In other words, the value of the friction angle is approximately the same, probably since permeation grouting with low injection pressures does not cause any disturbance of particle assembly (Cambefort 1967). Similar results have been found by Dupas and Pecker (1979) on mortars, and by Clough and Sitar (1981) on natural weakly cemented sands.

The values obtained for the cohesion $c^{\prime}$ (Table 4) confirmed the influences of the sand characteristics, the binder, and the cement content. These effects can be formally introduced by the following equation, obtained by combining Eqs. (6) and Eq. (9b):

$$
c^{\prime}=\frac{1-\sin \varphi^{\prime}}{2 \times \cos \varphi^{\prime}} \times A_{\text {soil }}\left(D_{r}\right) \times A_{0}^{1-n_{1} \times D_{r}} \times\left(\frac{C}{W}\right)^{N\left(1-n_{1} \times D_{r}\right)}
$$



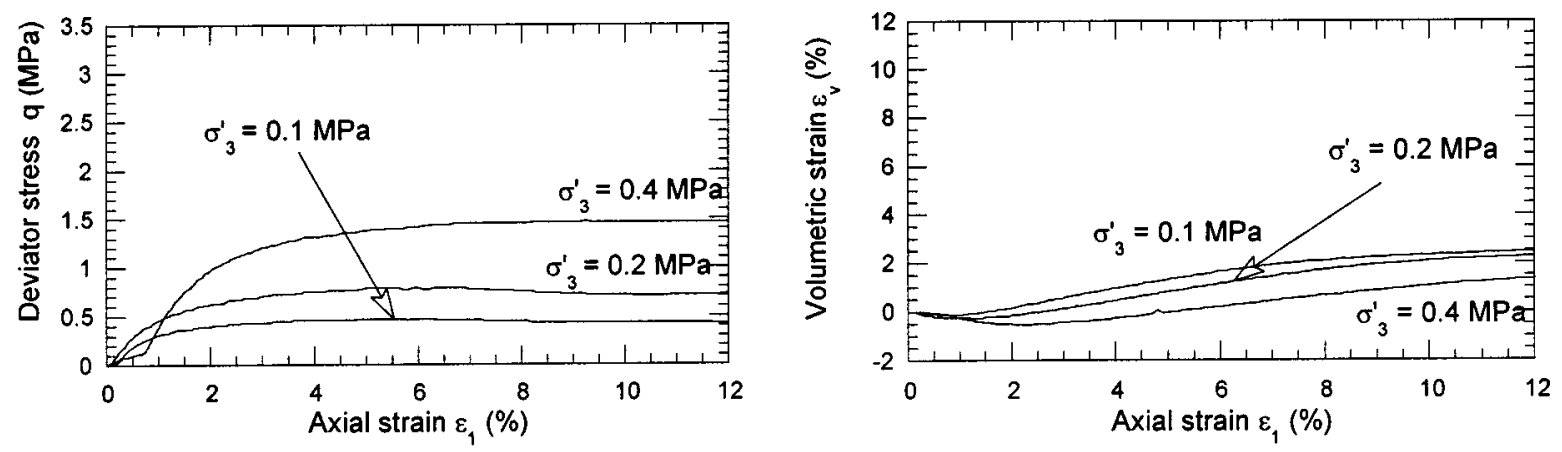

(6a) Seine River Sand
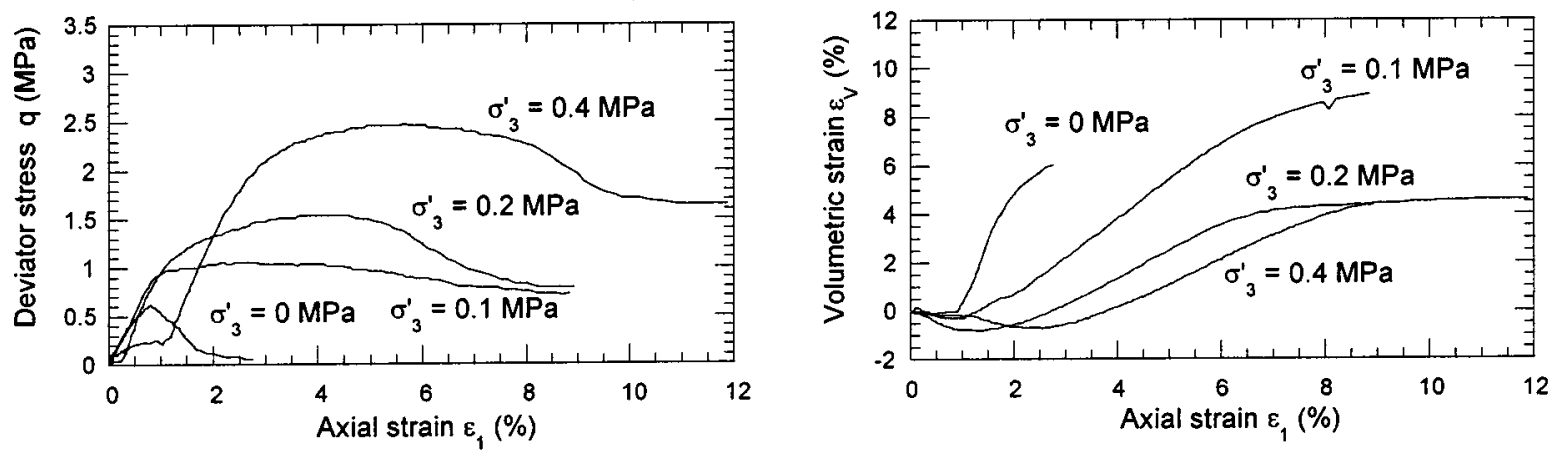

(6b) Seine River Sand + Cementitious Grout CG 1
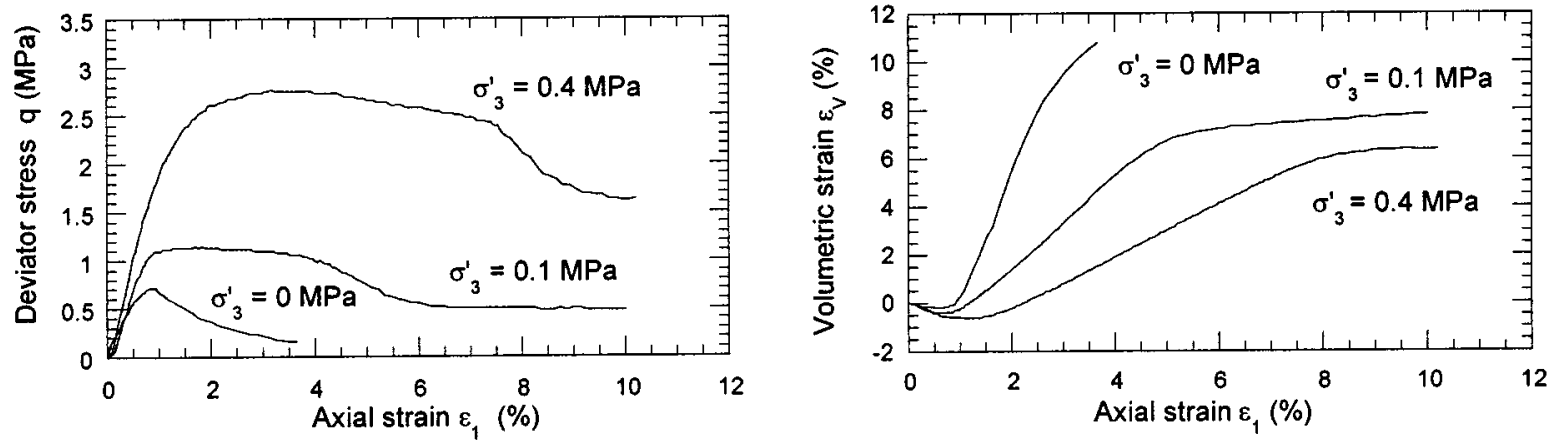

(6c) Seine River Sand + Mineral Grout MG 2

Fig. 6. Drained triaxial tests on Seine River sand prepared in laboratory (AFNOR P 94-074) ( $\sigma_{3}^{\prime}=$ constant effective lateral stress during triaxial tests)

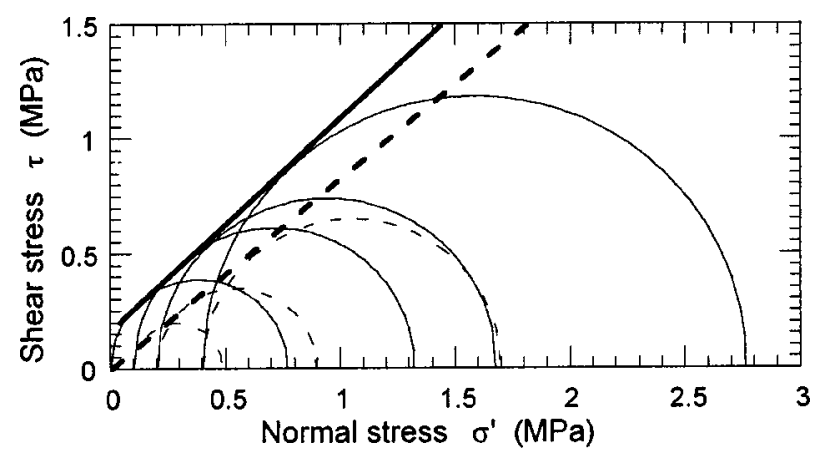

Fig. 7. Mohr-Coulomb failure envelope for Fontainebleau sand: pure (lower line) and improved by mineral grout MG2 (upper line)
Table 4. Values of Effective Stress Cohesion $c^{\prime}$ and Effective Stress Friction Angle $\varphi^{\prime}$

\begin{tabular}{lcccccc}
\hline & \multicolumn{2}{c}{$\begin{array}{c}\text { Fontainebleau } \\
\text { sand (FS) }\end{array}$} & & \multicolumn{2}{c}{$\begin{array}{c}\text { Seine River } \\
\text { sand (SRS) }\end{array}$} \\
\cline { 2 - 3 } \cline { 6 - 7 } Elements & $\begin{array}{c}\varphi^{\prime} \\
\text { (degrees) }\end{array}$ & $\begin{array}{c}c^{\prime} \\
\text { (MPa) }\end{array}$ & & $\begin{array}{c}\varphi^{\prime} \\
\text { (degrees) }\end{array}$ & $\begin{array}{c}c^{\prime} \\
(\mathrm{MPa})\end{array}$ \\
\hline Natural sand & 39 & 0 & & 40 & 0 \\
Sand+cementitious grout (CG1) & 42 & 0.2 & & 42 & 0.18 \\
Sand+cementitious grout (CG2) & 43 & 0.3 & & 43 & 0.25 \\
Sand+cementitious grout (CG3) & 44 & 0.5 & & 44 & 0.35 \\
Sand+mineral grout (MG1) & 42 & 0.125 & & 43 & 0.1 \\
Sand+mineral grout (MG2) & 42 & 0.2 & & 43 & 0.125 \\
Sand+mineral grout (MG3) & 40 & 0.45 & & 42 & 0.4 \\
\hline
\end{tabular}


Table 5. Values of Secant Modulus E, Poisson's Ratio $v$, and Dilation Angle $\psi$

\begin{tabular}{lcccc}
\hline Sand & $\begin{array}{c}\sigma_{3}^{\prime a} \\
(\mathrm{MPa})\end{array}$ & $\begin{array}{c}E \\
(\mathrm{MPa})\end{array}$ & $v$ & $\begin{array}{c}\psi \\
\text { (degrees) }\end{array}$ \\
\hline Fontainebleau sand (FS) & 0.1 & 63 & & 15.2 \\
& 0.2 & 117 & 0.3 & 14.0 \\
& 0.4 & 252 & & 13.1 \\
Fontainebleau sand (FS)+ & 0.1 & 332 & - & 27.0 \\
cementitious grout (CG1) & 0.2 & 406 & & 24.0 \\
& 0.4 & 790 & & 22.0 \\
Fontainebleau sand (FS)+ & 0.1 & - & - & - \\
cementitious grout (CG2) & 0.2 & 630 & & - \\
& 0.4 & 630 & & - \\
Seine River sand (SRS) & 0.1 & - & 0.31 & 9.7 \\
& 0.2 & 74 & & 8.4 \\
Seine River sand (SRS)+ & 0.4 & 97 & & 5.9 \\
cementitious grout (CG1) & 0.1 & 112 & - & 27.0 \\
& 0.2 & 180 & & 21.4 \\
Seine River sand (SRS)+ & 0 & - & & 19.6 \\
mineral grout (MG2) & 0.4 & 180 & - & - \\
& 0.4 & 240 & & 29.8 \\
\hline
\end{tabular}

$\overline{{ }^{\mathrm{a}} \sigma_{3}^{\prime} \text { is major principal effective stress }\left(\boldsymbol{\sigma}^{\prime}<0 \text { in compression) applied }\right.}$ during triaxial test.

Volume measurements indicate that grouted sands have a contractive-dilatant behavior (Figs. 5 and 6). However, when compared with uncemented sands, the contractancy domain is slightly reduced and the slope in the volumetric strain in the dilatancy stage increases (Table 5). Poisson's ratio $v$ is deduced from the initial slope of the curve in the contractancy domain [Eq. (11)], whereas the dilation angle $\psi$ is conventionally related to the maximum slope of the $\varepsilon_{v}-\varepsilon_{1}$ curve [Eq. (12)], at the inflection point in the dilatant stage, as follows:

$$
\begin{gathered}
\left(\frac{\Delta \varepsilon_{v}}{\Delta \varepsilon_{1}}\right)=1-2 v \\
\left(\frac{\Delta \varepsilon_{v}}{\Delta \varepsilon_{1}}\right)_{\max }=\left(\frac{-2 \times \sin \psi}{1-\sin \psi}\right)
\end{gathered}
$$

However, the values of $\psi$ have to be considered only in a qualitative way insofar as the grouted sands are concerned, at least for the lower confining pressures. Indeed, as previously mentioned, the grouted soils showed a brittle behavior under low confining pressures (vertical cracks) and more ductile behavior as the confining pressure increased (strain localization). The postpeak behavior is no longer representative, since failure systematically occurred in a localized mode.

The prefailure behavior and the pseudoelastic properties were, therefore, investigated further. The stress-strain curves (Figs. 5 and 6) show an almost linear initial part that extends over a large range of strains, but ends slightly before reaching the peak stress. Nevertheless, the pseudolinear elastic behavior provides a rough estimate. Also, the value of the secant modulus $E$ determined at the beginning of the stress-strain curve in the strain range close to $0.1 \%$ [Eq. (13)], as well as the maximum value of the deviator stress $q$, depend on the cement content, the nature and density of the granular material, the nature of the grout (Table 5), and the effective stress $\sigma_{3}^{\prime}$

$$
E=\frac{\Delta q}{\Delta \varepsilon_{1}}
$$

The value of $E$ is overestimated because of bedding errors during triaxial tests, as described later. The secant modulus $E$, for a strain level equal to $0.1 \%$, increases linearly with the effective stress $\sigma_{3}^{\prime}$ for uncemented sands. The dependency of the secant modulus on the effective stress, for a strain level also equal to $0.1 \%$, is less pronounced for grouted sands, especially for high cement contents. Secant moduli for grouted sands are thus improved by a ratio of $2: 5$, depending on the mean stress value and on the nature and cement content of the grout, compared to secant moduli for uncemented sands, for the same strain level. Nevertheless, these improvement ratios of the secant modulus probably underestimate the improvement of the real elastic properties obtained for a strain level below $0.001 \%$ because of nonlinearity (Shibuya et al. 1992).

\section{GrindoSonic Tests}

Some more accurate measurements of the elastic properties have been completed in the very small-strain range $(0.0001 \% \leqslant \varepsilon$ $\leqslant 0.001 \%$ ). Such an investigation requires specific devices generally based on wave propagation. Devoted originally to tests on hardened concrete with values of the Young's modulus between $100 \mathrm{MPa}$ and $840 \mathrm{GPa}$, the nondestructive GrindoSonic method consists of measuring the fundamental resonant frequency of the samples (RILEM 1983; Allison 1988) and French Standard NF P 18-414. A mathematical application based on Spinner and Tefft (1961) is therefore used to identify two independent parameters describing an isotropic-linear-elastic material, among the following three parameters: the Young's modulus $\left(E_{\max }\right)$, the shear modulus $\left(G_{\max }\right)$ and the Poisson's ratio $(v)$. The GrindoSonic measurements on concrete samples were found to agree with conventional static measurements by local extensometry (Valette 1992).

The cylindrical 100-mm-diameter by 200-mm-height samples lie on an absorbent cover to avoid any worktop interference effects. The sample is excited by a mechanical impulse caused by one slight plastic hammer stroke. The resulting propagating complex wave is detected by a piezoelectric detector held in contact in a point with the tested sample. The wave is therefore converted into an electronic signal. The fundamental resonant frequency is automatically deduced by the analysis of this signal. Two pulse modes (torsion and bending) are required to determine the aforementioned elastic parameters, which are obtained by different positions of the hammer stroke and the detector. Finally, the results for individual samples can be corroborated by repeated analysis under constant conditions.

Allison (1988) indicated that the elastic parameters dynamically identified depend on the water content of the tested material. Therefore, the grouted sand samples were gently dried in the open air before they were tested.

Experimental results are provided in Table 6. Young's moduli in the very small-strain domain are 1 order of magnitude greater than the secant moduli statically determined from the stressstrain curve in triaxial testing, whereas the values for the Poisson's ratios were typically between 0.15 and 0.30 . This means that the behavior is nonlinear, with a progressive decrease of the secant modulus as the strain level increases. The behavior is assumed to be linear with a constant modulus for strains below about $0.001 \%$, as shown by many writers (Shibuya et al. 1992; Baig et al. 1997, for instance). 
Table 6. Elastic Properties Determined by Use of GrindoSonic Apparatus (AFNOR NF P 18-414-1993)

\begin{tabular}{|c|c|c|c|}
\hline Sand & $\begin{array}{l}E_{\max }{ }^{\mathrm{a}} \\
(\mathrm{GPa})\end{array}$ & $\begin{array}{c}G_{\max } \\
(\mathrm{GPa})\end{array}$ & $v$ \\
\hline $\begin{array}{l}\text { Fontainebleau sand }(\mathrm{FS})+ \\
\text { cementitious grout IJ1 }\end{array}$ & 9.1 & 3.9 & 0.18 \\
\hline $\begin{array}{l}\text { Fontainebleau sand }(\mathrm{FS})+ \\
\text { cementitious grout } \mathrm{IJ} 2\end{array}$ & 12.4 & 5.2 & 0.18 \\
\hline $\begin{array}{l}\text { Fontainebleau sand }(\mathrm{FS})+ \\
\text { cementitious grout IJ3 }\end{array}$ & 15.7 & 6.1 & 0.22 \\
\hline $\begin{array}{l}\text { Medium alluvial deposits (ADM)+ } \\
\text { cementitious grout IJ1 }\end{array}$ & 11.1 & 4.4 & 0.20 \\
\hline $\begin{array}{l}\text { Coarse alluvial deposits (ADC) } \\
+ \text { cementitious grout IJ1 }\end{array}$ & 11.9 & 5.2 & 0.14 \\
\hline Pure cementitious grout IJ1 & 1.4 & 0.5 & 0.40 \\
\hline
\end{tabular}

\section{Summary of Experimental Results}

The experimental results show that the behavior of grouted sands presents the same features as other cement-treated soils, namely a contractive-dilatant and mean stress-dependent behavior. Also, the stress-strain behavior of grouted sands is nonlinear, and stiffness and strength are greatly improved by grouting. Finally, a Mohr-Coulomb failure envelope seems to represent reasonably well the failure envelope for compressive stresses.

These experimental observations were supported by triaxial tests on samples of uncemented Dunkerque sand (Fig. 1, Table 1) and the same Dunkerque sand injected in situ or in the laboratory by a mineral grout. Although the results are not presented here, the strength of the grouted sands prepared in the laboratory was systematically lower than that obtained from the field samples. Since the friction angle was found to be equal in both cases, the strength decrease means that the different preparation processes affected the cohesion. The decrease in cohesion for laboratory prepared samples can be attributed to the injection process. For the field conditions, an initially high pressure is required to break down the sleeve grout. This breakdown extends also to the soil, creating some zones with a greater quantity of grout than the quantity necessary to impregnate the sand. On the other hand, the laboratory conditions are well controlled and induce a homogeneous permeation of the grout through the sand.

\section{Recommendations for Design}

A simple linear elastic-perfectly plastic Mohr-Coulomb model is often used for design in sandy soils. Even if it only roughly represents the soil behavior, its simplicity makes it popular among geotechnical engineers. The triaxial test results give qualitatively similar results for grouted sands as for natural sands of medium to high relative density, i.e., a contractive-dilatant behavior as well as frictional and cohesive characteristics in the plastic domain. Therefore, the Mohr-Coulomb model was extended to grouted sands. This model is defined by the yield surface $F$ [Eq. (8)] and by a nonassociated flow rule that allows the dilatant behavior of a densely compacted granular soil to be represented more precisely. The plastic potential function, $G\left(\boldsymbol{\sigma}^{\prime}\right)$, is expressed as follows:

$$
G\left(\boldsymbol{\sigma}^{\prime}\right)=\left(\sigma_{3}^{\prime}-\sigma_{1}^{\prime}\right)+\left(\sigma_{3}^{\prime}+\sigma_{1}^{\prime}\right) \times \sin \psi
$$

$$
d \varepsilon_{i j}^{p}=\lambda \times \frac{\partial G}{\partial \sigma_{i j}}
$$

A nonassociated flow rule was chosen because the measured dilation angles were systematically lower than the friction angle.

Based on the previous experimental work, improvement ratios $X^{*}$ will be defined as the ratio between a property obtained after injection, $X_{p}$, and the same property before any treatment, $X_{b}$, or $X^{*}=X_{p} / X_{b}$. These ratios have been integrated into the technical specifications for underground construction works in Paris. Geotechnical investigations are commonly carried out to assess the soil characteristics before treatment. Depending on the objective of the grout injection (soil mechanical reinforcement or permeability reduction), characteristics of the grout will be defined, particularly its cement-to-water ratio. For design purposes, mechanical properties of the grouted soil can be calculated using the improvement ratios adapted to the chosen grout. The following improvement ratios are proposed:

1. The value of the Poisson's ratio, for uncemented sands as well as for grouted sands, is between 0.15 and 0.30 . No distinct correlation was found between the two materials and the Poisson's ratio for the grouted sand can be considered as equal to the Poisson's ratio of the uncemented sand, i.e., $v^{*}=1$.

2. Experiments have also shown that the value of the friction angle was hardly changed by permeation grouting. Consequently, it can be determined by carrying out conventional triaxial tests on the uncemented sand with a density close to the in situ one, such that $\varphi^{* *}=1$.

3. It is difficult to propose a clear improvement ratio for the dilation angle since mechanisms responsible for dilation are probably not similar, due to irreversible grain displacements and rotations in the case of uncemented sands, and damage crack opening in the case of grouted sands, at least for low mean stresses and high cement-to-water ratios. Therefore, the dilation angle for grouted sands is at least equal to the dilation angle of the uncemented sands: $1 \leqslant \psi^{*} \leqslant 1.5$.

4. The improvement ratio for the pseudoelastic properties (secant modulus in particular) not only depends on the cementto-water ratio, the mean stress and the soil characteristics, but also on the strain level. For secant moduli at a strain level of $0.1 \%, E^{*}$ is set to a value greater than 2 for a consolidation grouting, for the same mean effective stress. But failure can occur not far from such a strain level. Consequently it is more advisable to compare the Young's moduli in the very small-strain range where $E_{\max }^{*}$ can reach a value close to 10 . Further investigations are planned to correlate the elastic modulus of the grouted sand to the elastic modulus of both the grout and the uncemented sand.

5. Assuming that the cohesion of the uncemented soil is 0 , the increase of the cohesion depends on the cement-to-water ratio of the grout and the relative density of the soil, as stated by Eq. (10). It can be calculated from unconfined compression tests on the pure grout and on the grouted sand and from conventional triaxial tests on the uncemented sand. The effect of the initial saturation of soil voids was not discussed here, but pore water generally induces a slight decrease of the cohesion due to the dilution of the grout in the water (Perret et al. 2000).

\section{Conclusions}

Grouted sands present the general characteristics of cemented soils and can be considered as an intermediate material between 
soil and concrete. Based on the results of triaxial tests, when a given sand is impregnated by a cementitious grout, the evolution of its mechanical behavior is as follows:

1. The friction angle is almost unchanged by the injection treatment.

2. The Mohr-Coulomb cohesion varies between 0.1 and 0.5 MPa depending on the cement content of the grout and the relative density of the soil and increases in proportion with the cement-to-water ratio.

3. The secant modulus, measured at an axial strain of $0.1 \%$, is increased by a factor equal at least to 2, referring to the experimental data of this work. This ratio should be greater for a reinforcement ground treatment and can reach 4-5, depending on the mean effective stress. In the very smallstrain domain, the increase of real elastic properties leads to higher values of improvement ratios.

4. The grouted sands show a contractive-dilatant response along a deviatoric stress path and Poisson's ratio is between 0.15 and 0.3 . The dilation angle of the grouted sand is at least equal to and usually higher than the dilation angle of the uncemented sand at the same dry density.

\section{Notations}

The following symbols are used in this paper:

$A_{0}, A_{\text {soil }}, B=$ parameters describing evolution of unconfined compression of pure grouts or grouted sands;

$C / W=$ cement to water ratio;

$c^{\prime}=$ Mohr-Coulomb effective stress cohesion;

$D_{r}=$ relative density;

$d_{x}=$ grain size at which $x \%$ of particles by weight are smaller;

$d_{50}=$ mean grain size of sand particles;

$E=$ secant modulus;

$E_{\max }=$ Young's modulus in small-strain domain;

$F(\boldsymbol{\sigma})=$ yield criterion;

$G_{\max }=$ shear modulus in small-strain domain;

$M / W=$ dry material to water ratio;

$n, N, n_{0}, n_{1}=$ parameters describing evolution of unconfined compression of pure grouts or grouted sands;

$q=$ deviator stress;

$R_{c}=$ unconfined compressive strength;

$R_{c, \mathrm{PG}}=$ unconfined compressive strength of pure grout;

$R_{\mathrm{TB}, \exp }=$ tensile strength measured by splitting tensile test;

$R_{\mathrm{TD}, \exp }=$ tensile strength measured by direct tensile test;

$R_{\mathrm{TD}, \text { the }}=$ tensile strength obtained with MohrCoulomb yield criterion;

$U_{c}=$ coefficient of uniformity $\left(U_{c}=d_{60} / d_{10}\right)$;

$\gamma=$ weight per unit of volume;

$\gamma_{\max }=$ maximum dry weight per unit of volume;

$\gamma_{\min }=$ minimum dry weight per unit of volume;

$\varepsilon, \varepsilon_{1}, \varepsilon_{V}=$ strain level, axial strain, and volumetric strain during triaxial tests, respectively;

$v=$ Poisson's ratio;

$\boldsymbol{\sigma}^{\prime}, \sigma_{1}^{\prime}, \sigma_{3}^{\prime}=$ stress tensor, minor principal effective stress, major effective principal stress;

$\sigma_{c}=$ confining pressure;

$$
\begin{aligned}
\varphi^{\prime}= & \text { Mohr-Coulomb effective stress friction } \\
& \text { angle; and } \\
\psi= & \text { dilation angle. }
\end{aligned}
$$

\section{References}

Airey, D. W. (1993). "Triaxial testing of naturally cemented carbonate soil." J. Geotech. Eng., 119(9), 1379-1398.

Allison, R. J. (1988). "A nondestructive method of determining rock strength." Earth surface processes and landforms, Vol. 13, Wiley, New York, 1-8.

Baig, S., Picornell, M., and Nazarian, S. (1997). "Low strain shear moduli of cemented sands." J. Geotech. Geoenviron. Eng., 123(6), 540-545.

Baligh, M. M. (1976). "Cavity expansion in sand with curved envelopes." J. Geotech. Eng. Div., Am. Soc. Civ. Eng., 102(11), 11311146.

Benhamou, O. (1994). "Comportement rhéologique des coulis de liants hydrauliques ultrafins destinés à l'injection." $\mathrm{PhD}$ thesis, Ecole de Géologie de l'Ingénieur, Ecole Nationale Supérieure des Mines de Paris (in French).

Bishop, A. W. (1966). "The strength of soils as engineering materials." Geotechnique, 16(2), 91-128

Bouvard-Lecoanet, A., Colombet, G., and Esteulle, F. (1992). Ouvrages souterrains: Conception-réalisation-entretien, 2nd Ed., Presses de l'E.N.P.C. (in French).

Cambefort, H. (1967). L'injection des sols, Eyrolles (in French).

Clough, G. W., and Sitar, B. (1981). "Cemented sands under static loading." J. Geotech. Eng. Div., Am. Soc. Civ. Eng., 107(6), 799-817.

Dano, C., and Derache, N. (2001). "Grout injection in the laboratory." Proc., Landmarks in Earth Reinforcement, Int. Symp. on Earth Reinforcement, Fukuoka, Japon, 21-26.

Dupas, J. M., and Pecker, A. (1979). "Static and dynamic properties of sand-cement." J. Geotech. Eng. Div., Am. Soc. Civ. Eng., 105(3), 419-436.

Gouvenot, D. (1995). "Silacsol: plus qu'un coulis, un nouveau procédé d'injection des sols." Tunnels Ouvrages Souterrains, 127, 17-25 (in French).

Hoek, E., and Brown, E. T. (1980). "Empirical strength criterion for rock masses." J. Geotech. Eng. Div., Am. Soc. Civ. Eng., 106(9), 10131035.

Huang, J. T., and Airey, D. W. (1998). "Properties of artificially cemented carbonate sand." J. Geotech. Geoenviron. Eng., 124(6), 492-499.

Kaga, M., and Yonekura, R. (1991). "Estimation of strength of silicategrouted sand." Soils Found., 31(3), 43-59.

Kutzner, C. (1996). Grouting of rock and soil, Balkema, Rotterdam, The Netherlands.

Perret, S., Khayat, K. H., and Ballivy, G. (2000). "The effect of degree of saturation of sand on groutability-Experimental simulation." Ground Improvement, 4(4), 13-22.

RILEM. (1983). "Recommandations pour l'emploi de la méthode de fréquence de résonance dans le contrôle des éprouvettes de béton." GrindoSonic user manual, France.

Saxena, S. K., and Lastrico, R. M. (1978). "Static properties of lightly cemented sand." J. Geotech. Eng. Div., Am. Soc. Civ. Eng., 104(12), 1449-1464.

Schillinger, L., Vulliet, L., Bouchelaghem, F., Leroy, D., Laloui, L., and Descoeudres, F. (2000). "Injection of micro-cement in fine-grained soil: theory, modelling and laboratory testing." Darmstädter geotechnik-kolloquium, Technischen Univ. Darmstad, Darmstadt, Germany 157-175.

Schwarz, L. G., and Krizek, R. J. (1994). "Effect of preparation technique on permeability and strength of cement-grouted sand." Geotech. Test. J., 17(4), 434-443.

Shibuya, S., Tatsuoka, F., Teachavorasinskun, S., Kong, X. J., Abe, F., Kim, Y. S., and Park, C. S. (1992). "Elastic deformation properties of 
geomaterials." Soils Found., 32(3), 26-46.

Spinner, S., and Tefft, W. E. (1961). "A method for determining mechanical resonance frequencies and for calculating elastic moduli from these frequencies." American Society Testing Material Proc., 61, 1221-1238.

Tailliez, S. (1998). "Etude expérimentale du comportement mécanique des sols granulaires injectés." PhD thesis, Ecole Centrale de Paris, Paris (in French).

Valette, D. (1992). Internal Rep., Bouygues Society.

Zebovitz, S., Krizek, R. J., and Atmatzidis, D. X. (1989). "Injection of fine sands with very fine cement grout." J. Geotech. Eng., 115(12), $1717-1733$. 